Abstracta Iranica Abstranica

Revue bibliographique pour le domaine irano-aryen

Volume 42-43 | 2021

Comptes rendus des publications de 2019-2020

\title{
Jonathan Brack, "Rashīd al-Dīn: Buddhism in Iran and the Mongol Silk Roads"
}

\section{Simon Berger}

\section{OpenEdition}

1 Journals

\section{Édition électronique}

URL : https://journals.openedition.org/abstractairanica/53807

DOI : 10.4000/abstractairanica.53807

ISSN : 1961-960X

Éditeur :

CNRS (UMR 7528 Mondes iraniens et indiens), Éditions de l'IFRI

Référence électronique

Simon Berger, "Jonathan Brack, "Rashīd al-Dīn: Buddhism in Iran and the Mongol Silk Roads" », Abstracta Iranica [En ligne], Volume 42-43 | 2021, document 33, mis en ligne le 30 décembre 2021, consulté le 29 décembre 2022. URL : http://journals.openedition.org/abstractairanica/53807 ; DOI : https://doi.org/10.4000/abstractairanica.53807

Ce document a été généré automatiquement le 29 décembre 2022.

Tous droits réservés 


\title{
Jonathan Brack, "Rashīd al-Dīn: Buddhism in Iran and the Mongol Silk Roads"
}

\author{
Simon Berger
}

\section{RÉFÉRENCE}

Jonathan Brack, "Rashīd al-Dīn: Buddhism in Iran and the Mongol Silk Roads" in M.

Biran, J. Brack, F. Fiaschetti (eds.). Along the Silk Roads in Mongol Eurasia: Generals,

Merchants and Intellectuals. Oakland : University of California Press, 2020, p. 215-237.

1 La connaissance pointue du bouddhisme dont le célèbre vizir et historien ilkhanide Rashīd ad-Dīn témoigne, aussi bien dans son œuvre historique (l'Histoire de l'Inde et l'Histoire de la Chine incluse dans le second volume du Jāmi' at-tavārikkh) que dans son œuvre philosophique, témoigne de la circulation intense des hommes, des objets et des savoirs au sein de l'Eurasie mongole. Il est en effet connu que Rashīd ad-Dīn a conversé, et débattu, avec des moines bouddhistes venus d'Inde, du Tibet ou du Cachemire en Iran et présents à la cour des ilkhan (notamment le moine Kamālashrī). Mais a aussi manifestement pu consulter, directement ou indirectement, pu consulter des traités et chroniques bouddhistes composées dans la Chine des Yuan. L'A. montre également qu'au-delà de son rôle de passeur, Rashīd ad-Dīn présentant le bouddhisme à son public sous un jour familier et acceptable, celui-ci insiste dans le même temps sur sa différence avec l'islam, et finalement sur la supériorité de ce dernier. 


\section{AUTEURS}

SIMON BERGER

Doctorant EHESS, CETOBAC, Paris 